\title{
FLORA DE GRÃO-MOGOL, MINAS GERAIS: VITACEAE ${ }^{1}$
}

\author{
JULIO ANTONIO LOMBARDI \\ Departamento de Botânica, Instituto de Ciências Biológicas, Universidade Federal de Minas Gerais, \\ Av. Antônio Carlos 6627, Pampulha, 31270-110 - Belo Horizonte, MG, Brasil.
}

BAKER, J.G. 1871. Ampelideae. In C.F.P. Martius \& A.G. Eichler (eds.). Flora brasiliensis. Frid. Fleischer. Leipzig, vol. 14, pars 2, p. 197-220.

LOMBARDI, J.A. 2000. Vitaceae: gêneros Ampelocissus, Ampelopsis e Cissus. Fl. Neotrop. Monogr. 80: 1-250.

PLANCHON, J.E. 1887. Monographie des Ampélidées vraies. In A.L.P.P. de Candolle \& A.C. de Candolle (eds.) Monographiae phanerogamarum. G Masson. Paris, vol. 5, pars 2, p. 305-654.

\section{Cissus L.}

Lianas. Ramos vegetativos de crescimento indefinido produzindo ramos reprodutivos curtos e sazonais. Gavinhas opostas às folhas. Folhas alternas, estipuladas, simples ou compostas. Inflorescências opostas às folhas, cimeiras compostas de ápice aplanado. Flores hermafroditas, tetrâmeras; cálice gamossépalo; pétalas de prefloração valvar, induplicadas, coerentes entre si em caliptra, geralmente caducas; estames 4, anteras com deiscência longitudinal; disco nectarífero mais ou menos 4-lobado, geralmente cobrindo e adnato ao ovário; ovário súpero, bilocular; estilete 1, central; estigma 1, apical. Fruto baga, quase sempre com uma semente.

1.1. Cissus inundata (Baker) Planch. in A.DC. \& C.DC., Monogr. phan. 5(2): 537. 1887.

Ramos esparso-aculeados, glabros a esparso vilosos. Gavinhas ramificadas, com discos adesivos. Estípulas de ca. 3,5 mm compr., 1,7 mm larg., triangulares, caducas. Pecíolos 1,6-3,8 cm compr., alados, vilosos a glabrescentes; folhas ternadas, glabras a esparso-pubérulas na face ventral, na dorsal vilosas ao longo das nervuras, denticuladas, cartáceas; folíolos de ápice agudo, base atenuada, às vezes lobulados, centrais 4-10,3 cm compr., 2-5,6 cm larg., rômbicos; laterais 2,6-7,6 cm compr., 1,3-3,65 cm larg., subovais a subelípticos. Inflorescência ca. 2,2 cm compr., ca. 1,9 cm larg., brácteas triangulares, pedicelos 1,9-2 $\mathrm{mm}$ compr., esverdeados, esparso pilosos a glabrescentes. Cálice de 1,2-1,8 mm diâm., esverdeado, esparsamente piloso-glandular; corola em botão ca. 1,2 mm alt., 1,2-1,5 mm diâm., rosada, esparso-pilosa no ápice a glabra; anteras de conectivo subpentagonal, granuloso, extrorsas; disco esverdeado, ápice aplanado, elevado em volta dos filetes. Baga ca. $6 \mathrm{~mm}$ diâm., esférica, púrpura; semente subesférica. (Fig. 1. A-E)

Cordeiro et al. CFCR 797 (SPF, UEC); Kameyama et al. CFCR 9005 (SPF, UEC); Pirani et al. CFCR 12488 (SPF, UEC).

Endêmica do norte de Minas Gerais, nos campos rupestres; pouco conhecida. Em Grão-Mogol, ocorre na borda de matas ciliares e entre pedras no campo rupestre. Floresce de dezembro a abril e frutifica no mesmo período. Cissus inundata está incluída na lista de espécies ameaçadas de extinção de Minas Gerais.

${ }^{1}$ Trabalho realizado conforme o planejamento apresentado por Pirani et al. 2003. Bol. Bot. Univ. São Paulo 21(1): 1-24. 


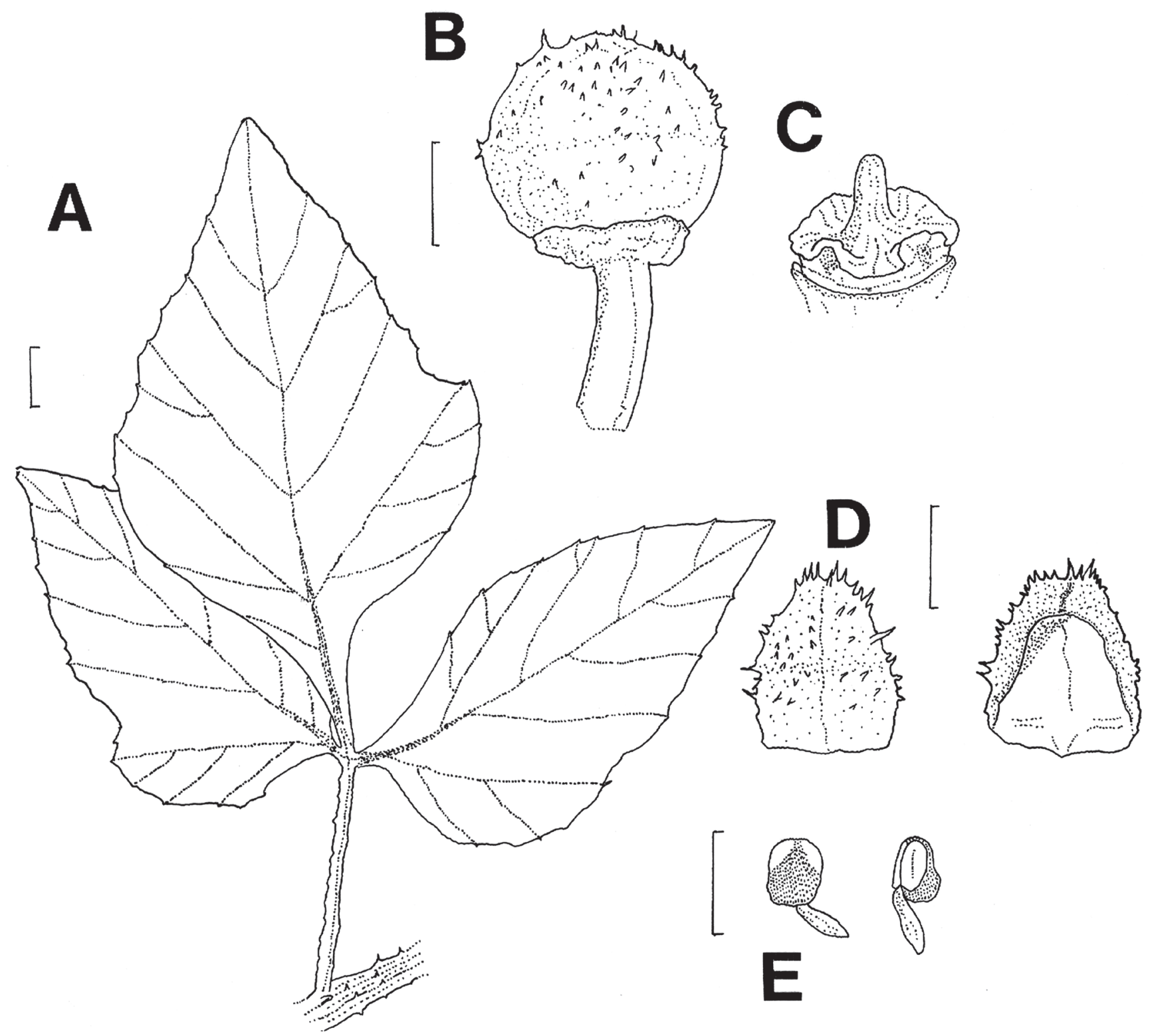

Fig. 1. VITACEAE. Cissus inundata. A. Hábito, folha do ramo vegetativo; B. Botão; C. Aspecto superior do disco nectarífero; D. Pétalas, vista dorsal e ventral; E. estames, vista ventral e lateral. (Escala: $1 \mathrm{~cm}(\mathrm{~A}), 1 \mathrm{~mm}(\mathrm{~B}-\mathrm{E})$. 